\title{
The adaptor protein NumbL is involved in the control of glucolipotoxicity-induced pancreatic beta cell apoptosis
}

Halesha D. Basavarajappa ${ }^{1}$, Jose M. Irimia ${ }^{1,2}$, Patrick T. Fueger ${ }^{1,2}$

${ }^{1}$ Department of Molecular and Cellular Endocrinology, and ${ }^{2}$ Comprehensive Metabolic Phenotyping Core, Beckman Research Institute of City of Hope, 1500 E. Duarte Rd., Duarte, CA 91010, USA.

Correspondence to:

Patrick T. Fueger, PhD

Department of Molecular \& Cellular Endocrinology

Director, Comprehensive Metabolic Phenotyping Core

Beckman Research Institute of City of Hope

1500 E. Duarte Rd.

Duarte, CA 91010, USA

Email: pfueger@coh.org

Phone: 626-218-062 


\section{Abstract}

2 Avoiding loss of functional beta cell mass is critical for preventing or treating diabetes. Currently,

3 the molecular mechanisms underlying beta cell death are partially understood, and there is a

4 need to identify new targets for developing novel therapeutics to treat diabetes. Previously, our

5 group established that Mig6, an inhibitor of EGF signaling, mediates beta cell death under

6 diabetogenic conditions. The objective of this study was to clarify the mechanisms linking

7 diabetogenic stimuli to beta cell death by investigating Mig6-interacting proteins. Using co-

8 immunoprecipitation and mass spectrometry, we evaluated the binding partners of Mig6 under

9 both normal glucose (NG) and glucolipotoxic (GLT) conditions in beta cells. We identified that

10 Mig6 interacts dynamically with NumbL; whereas Mig6 associates with NumbL under NG, this

11 interaction is disrupted under GLT conditions. Further, we demonstrate that siRNA-mediated

12 suppression of NumbL expression in beta cells prevented apoptosis under GLT conditions by

13 blocking activation of NF-kB signaling. Using co-immunoprecipitation experiments we observed

14 that NumbL's interactions with TRAF6, a key component of NFkB signaling, are increased

15 under GLT conditions. The interactions among Mig6, NumbL, and TRAF6 are dynamic and

16 context-dependent. We propose a model wherein these interactions activate pro-apoptotic NF-

17 KB signaling while blocking pro-survival EGF signaling under diabetogenic conditions, leading to

18 beta cell apoptosis. These findings indicate that NumbL should be further investigated as a

19 candidate anti-diabetic therapeutic target.

20

21 Keywords: diabetes, epidermal growth factor, glucolipotoxicity, beta cell, apoptosis, Mig6,

22 NumbL, NF-kB signaling, apoptosis, Notch signaling. 


\section{Introduction}

Diabetes is a complex metabolic disorder affecting nearly 463 million people worldwide according to the International Diabetes Federation. The disease is characterized by increased blood glucose levels due to an imbalance in whole-body glucose homeostasis. Insulin-secreting pancreatic beta cells play a key role in controlling glucose homeostasis, and the depletion of functional beta cell mass is central to the manifestation of diabetes [1]. Hence, preventing beta cell loss or restoring functional beta cell mass remain major challenges in finding cures for diabetes.

Functional beta cell mass is modulated by multiple processes such as beta cell proliferation, beta cell hypertrophy, insulin secretory capacity, and apoptosis. During the development of type 2 diabetes (T2D), initially pancreatic beta cell mass increases to maintain glucose homeostasis under chronic nutrient oversupply and peripheral insulin resistance conditions [2]. This increase in beta cell mass compensates for the increased insulin demand under excess glucose levels and is partially driven by low levels of ER stress through unfolded protein response [3] .

37 However, if the secretory burden persists, unresolved ER stress leads to beta cell death [4, 5]. Moreover, the glucolipotoxic (GLT) milieu (elevated levels of both glucose and lipids), prevalent

39 in diabetic conditions, further deteriorates the survival capacity of beta cells [6-9]. Once

40 functional beta cell mass declines, overt T2D arises [10]. Understanding the molecular events

41 leading to pancreatic beta cell death under diabetogenic conditions is essential for discovering

42 new therapies to prevent or cure diabetes. Apoptosis is a major pathway for the beta cell death

43 [11] and is induced by absence of pro-survival signals such as EGF signaling [12] and activation

44 of proapoptotic pathways such as NF-kB signaling [13]. 
It is well established that GLT induces NF-KB signaling, and this pathway induces beta cell apoptosis $[13,14]$. Inactive NF-kB is bound to an inhibitor protein, IkB, and sequestered in the cytosol. The NF-KB pathway is activated when IKBa is phosphorylated and degraded to release free NF-kB. Once free of inhibition, NF-kB is phosphorylated and migrates to the nucleus to regulate transcription [15]. This degradation of IKBa is initiated by a sequence of events

50 involving IKK, NEMO and TRAF6 [15, 16]. TRAF6, upon activation, is polyubiquitinated and

51 then activates NEMO and IKK, which in turn phosphorylate IKBa [16]. However, how NF-KB signaling is activated under GLT is not clearly understood.

In addition to the induction of proapoptotic pathways, the absence of pro-survival signals

54 also contributes to beta cell apoptosis. Among the many proliferative pathways characterized,

55 epidermal growth factor receptor (EGFR) signaling is crucial for both beta cell proliferation and

56 survival $[12,17]$, and EGF treatment has been reported to induce beta cell proliferation and

57 restore beta cell mass in rodents [18]. However, EGF signaling is impaired during beta cell stress, as occurs in T2D [19].

Previously, our group has demonstrated that Mig6, an inhibitor of EGFR signaling, plays a key role in beta cell apoptosis under diabetogenic conditions [19-21]. Upon induction, Mig6

61 binds to the EGF receptor and blocks pro-proliferative signaling [22]. Moreover, we have 62 observed that under GLT conditions, Mig6 levels are elevated, and EGFR signaling is inhibited 63 (Y-C Chen and PT Fueger, personal communications). Although Mig6 is considered a molecular 64 brake for proliferation, it also antagonizes beta cell survival and impairs beta cell function [19, 65 20]. Thus, strategies for suppressing Mig6 action in beta cells could improve the retention of 66 functional beta cell mass. 
The objective of this study was to better understand how GLT regulates beta cell death by

68 investigating Mig6 binding partners. We discovered that Mig6 dynamically interacts with the

69 adaptor protein NumbL, a component of Notch signaling [23, 24]. Furthermore, we delineated a

70 novel role for NumbL in beta cell apoptosis, and we propose that reducing NumbL could be

71 exploited to prevent beta cell death under glucolipotoxic conditions.

\section{Results:}

\subsection{Mig6 dynamically interacts with NumbL protein:}

Although Mig6 was initially considered as a stress-inducible gene, increasing reports

indicate that it contributes to beta cell death under stressed conditions $[19,20,30]$. To clarify the

mechanisms underlying diabetogenic beta cell death, we sought to identify Mig6 associating partners in a GLT cell culture model, which mimics the diabetic milieu [31, 32]. To identify

78 potential interacting protein partners of Mig6, we overexpressed FLAG-tagged Mig6 protein in

79 Ins-1-derived 832/13 cells using adenovirus and exposed the cells to NG or GLT conditions for

12 h. Using an anti-FLAG antibody, we immunoprecipitated Mig6 along with its interacting

81 proteins and identified the associating proteins using mass spectrometry (Figure 1A). As Mig6

82 is an adaptor protein, it was expected that multiple proteins bind to Mig6 (Figure 1A). Hence,

83 we screened for interacting proteins whose binding pattern with Mig6 was significantly altered

84 with changes in the glucolipotoxic milieu of the culture conditions (Figure 1B). Additionally,

85 protein components of the cytoskeleton system such as actin, spectrin, and myosin would be

86 ignored. Given the goals of the screen, we focused on proteins reported to be involved in EGF

87 and/or NF-kB signaling. We then confirmed the results by immunoblot analysis and reverse co-

88 immunoprecipitation experiments (Figure 1C-D). We observed that Mig6 interacted dynamically 
with NumbL protein, showing strong association under NG conditions and weaker association under GLT conditions (Figure 1C-D).

To verify that the decreased binding was not due to decreased expression levels of NumbL, we measured both the mRNA and protein levels of NumbL under both NG and GLT conditions at various time points (Figure 2). We detected no change in the levels of NumbL in 832/13 cells exposed to GLT conditions, suggesting that the interaction between Mig6 and NumbL is dynamic and not determined solely by protein abundance. Similarly, primary human islets cultured in GLT conditions for $48 \mathrm{~h}$ exhibited no change in NumbL expression levels (Figure 2D). Further, we measured NumbL mRNA levels in primary islets from patients with prediabetes (HbA1c level between 5.7-6.4\%) and T2D (HbA1C levels > 6.4\%) (Figure 2C). Although there were no significant changes in expression levels between controls $(\mathrm{HbA} 1 \mathrm{C}$ levels $<5.7 \%$ ) and patients with diabetes, surprisingly there was a significant decrease in

101 NumbL between the control and pre-diabetic groups. Further investigation is required to understand this difference in the NumbL levels between control and pre-diabetic subjects.

\subsection{Down regulation of NumbL prevents glucolipotoxicity-induced beta cell apoptosis:}

As Mig6 has been implicated in inducing beta cell apoptosis under stressed conditions, we investigated the role of its interacting protein, NumbL, in beta cell apoptosis under GLT conditions. As depicted in Figure 3A, GLT induced apoptosis in 832/13 cells in a timedependent manner, as measured by cleaved caspase 3 activity. To test the role of NumbL, we used siRNA knockdown and confirmed over $80 \%$ suppression of NumbL expression by

109 immunoblot analysis (Figure 3B). The activation of apoptosis with GLT was significantly 
The prevention of beta cell apoptosis under GLT prompted us to test the extent to which

113 NumbL down regulation resolved ER stress induced by GLT. However, there was no significant 114 change in GLT-induced ER stress between the siRNA control and siNumbL groups, as measured by the levels of phospho-elF2a (Supporting Information Figure S1).

\subsection{Reducing NumbL does not enhance beta cell proliferation and insulin secretion}

In lung cancer cell lines, suppression of NumbL has been reported to promote cell proliferation [33]. Hence, we sought to determine the extent to which NumbL knock down in 832/13 cells induces beta cell proliferation using an EdU incorporation assay. However, NumbL

120 knock down did not induce significant proliferation as compared to control siRNA-treated cells 121 under either NG or GLT conditions (Supporting Information Figure S2A). This result is further corroborated by the observation that knock down of NumbL did not rescue the glucolipotoxicity-

Information Figure 2B). However, it is interesting to note that NumbL knock down significantly increased EGFR phosphorylation under NG conditions. Further, NumbL depletion did not affect beta cell function, as measured by glucose-stimulated insulin secretion (Supporting

\subsection{NumbL reduction does not activate Notch signaling in $832 / 13$ cells}

NumbL, along with its homologous protein Numb, were originally characterized as Notch signaling inhibitors and cell-fate-determining proteins [23, 24, 34]. Hence, we tested whether

131 knock down of NumbL activates Notch signaling in response to GLT conditions by monitoring 132 the levels of Hes-1, a downstream target gene of Notch signaling. Whereas Hes-1 expression 133 was increased under GLT conditions in 832/13 cells, knock-down of NumbL did not affect Notch 134 signaling (Supporting Information Figure S3A). Interestingly, we noticed that only the siRNA 
directed against Numb and not NumbL increased Hes-1 expression levels under GLT conditions. These observations indicate that under the studied conditions NumbL may not participate in Notch signaling in $832 / 13$ cells or that Numb is the major mediator of Notch inhibition in $832 / 13$ cells. These observations contrast with the functions of NumbL observed in other cell types [24] indicating tissue-specific variations in the functions of NumbL.

\subsection{Down regulation of NumbL prevents glucolipotoxicity-induced activation of the NF-кB}

141 pathway:

Several groups have reported that NF-kB pathway activation leads to apoptosis in beta cells under diabetogenic conditions $[13,35,36]$. In its inactive state, NF-kB is bound to the IkB 144 inhibitor protein and sequestered in the cytosol. Upon activation, IKBa is phosphorylated and degraded by the proteasome. Once free of inhibition, NF-kB is phosphorylated and migrates to the nucleus where it exerts its transcriptional function.

When either human islets (Figure 4A-C) or 832/13 cells (Figure 4D-G) were incubated in

153 mediates GLT-induced NF-KB pathway activation.

\subsection{NumbL interacts with TRAF6 in a context dependent manner:}

As NumbL down regulation inhibits NF-KB signaling under GLT, we evaluated the 
interactions between NumbL and TRAF6 under GLT in beta cells. As reported in Figure 5A, in

159 beta cells, endogenous NumbL and TRAF6 interact under NG conditions and this interaction is 160 increased nearly 2-fold under GLT conditions. To determine if this increased binding is simply due to increased expression of TRAF6, we measured TRAF6 protein levels under GLT over different time points (Figure 5B) and noted no significant increase in the TRAF6 expression

163 levels, indicating an increased interaction between NumbL and TRAF6 under GLT. In order to 164 further test the role of TRAF6 in activation of NF-kB signaling and apoptosis under GLT, we treated beta cells under GLT with different concentration of compound 6877002, an inhibitor of TRAF6 activation [39], and monitored the levels of lkBa levels (Figure 5C) and cleaved caspase-3 (Figure 5D). We observed that compound 6877002 decreased both NF-kB activation and beta cell apoptosis in a dose dependent manner.

\section{Discussion:}

In the present study, we discovered that Mig6 binds to NumbL under NG and this interaction

171 is disrupted under GLT. Conversely, NumbL interacts more abundantly with TRAF6 under GLT

172 than NG conditions. In addition, we established that NumbL down regulation prevents both the

173 activation of NF-kB signaling and beta cell apoptosis under GLT. The combined interactions of

174 Mig6, NumbL, and TRAF6, along with the pro-apoptotic nature of NumbL, may indicate that

175 these proteins regulate beta cell apoptosis under GLT. Further, we propose a model that under

176 NG conditions Mig6 is locked in an inactive complex with NumbL and thereby keeping pro-

177 survival EGF signaling active. When beta cells are exposed to GLT conditions, this Mig6-NumbL

178 complex is disrupted to release Mig6 and NumbL. The released Mig6 protein then binds to

179 EGFR and inhibits EGF signaling, meanwhile NumbL binds to and activates TRAF6 protein to

180 induce NF-KB signaling (Figure 5E). The results presented here are consistent with a model 
wherein GLT causes NumbL to switch from a Mig6-containing complex to a TRAF6-activating complex, thereby increasing pro-apoptotic signaling through NF-KB in beta cells (Figure 5E).

Given the known role for EGF signaling in pancreatic beta cell survival and proliferation [12, 17] and the ability of Mig6 to inhibit this pathway [40], we hypothesized that the Mig6 interacting partner NumbL would regulate EGF signaling. To our surprise, NumbL depletion significantly increased EGF signaling under NG and did not alter EGF signaling under GLT (Supporting Information Figure S2B). This increased EGF signaling under NG conditions can be partially be explained by the fact that NumbL, along with Numb protein, also participates in Erbb receptor (EGFR belongs to Erbb family of receptors) degradation as reported by others [34]. The observation that EGF signaling is increased under NG and impaired in GLT treated cells even after NumbL depletion indicates that the free Mig6 does not directly inhibit EGFR after release

192 from Mig6-NumbL complex. We believe that the free Mig6 protein in NumbL depleted cells still 193 needs to undergo posttranslational modifications before binding to EGFR and exerts its 194 inhibitory function. Our group has observed that under GLT conditions, Mig6 is upregulated and is responsible for EGFR signal impairment (unpublished data). Consistent with this idea, other 196 groups have reported that Mig6 undergoes extensive phosphorylation events before inhibiting 197 EGF signaling [40]). Hence, further investigations are required to decipher the role of NumbL in 198 EGF signaling in beta cells. It remains to be determined whether other factors, such as posttranslational modification of Mig6, play a role in mediating the dynamic relationship between 200 Mig6 and NumbL under GLT [40]. It also remains to be determined if the NumbL-Mig6 complex 201 locks Mig6 in an inactive form and whether other pathways are involved in GLT-induced beta 202 cell apoptosis. Bagnati et al. reported that under GLT, there is increased expression of CD40 receptors in beta cells [13] and CD40-TRAF6 interactions are known to activate the NF-kB 204 pathway $[13,41]$. Accumulation of NumbL-TRAF6 complex and initiation of NF-kB signaling 
under GLT suggests that NumbL plays a key role in activating NF-kB pathway. However, further investigations are warranted to understand how the TRAF6-NumbL complex activates the NFKB pathway. We hypothesize that NumbL promotes polyubiquitination of TRAF6, which in turn activates the IKK complex. It also remains to be determined if CD40 receptor binding to this NumbL-TRAF6 complex is required for NF-KB activation.

TRAF6 activity depends on its polyubiquitination [16], and it is not clear if TRAF6, being an

211 ubiquitin ligase, ubiquitinates itself or if other factors are involved [15, 16, 38]. Swarnker et al.

212 determined that NumbL promotes polyubiquitination of TRAF6 and NEMO in osteoclasts [38].

213 As polyubiquitinated TRAF6 is required for activation of NF-kB signaling and NumbL promotes

214 polyubiquitination of TRAF6, it is intuitive to predict that under GLT, NumbL activates TRAF6 to

215 induce NF-kB and thereby causing beta cell apoptosis. However, Swarnker et al. reported

216 NumbL negatively regulates NF-KB signaling in osteoclasts whereas we observe NumbL 217 activating NF-kB signaling. The contradictions in these results can be explained partly by the 218 difference in the context of the study, cell type and incubation time of the experiments. In our 219 study, we treated beta cells with GLT for a short period of time (1 to $12 \mathrm{~h}$ ) whereas Swarnker et 220 al. used a longer duration cell model (4 d) to study the effect of NumbL on TRAF6. In beta cells, 221 NF-KB activation starts within a couple of hours after exposure to GLT and apoptosis is induced 222 at approximately $8 \mathrm{~h}$ exposure to GLT. Because polyubiquitinated TRAF6 first initiates the NF$223 \mathrm{kB}$ pathway and then undergoes degradation, it is possible that we captured the initial phase of 224 the events, such as TRAF6 ubiquitination, IkBa degradation and NF-kB activation, that might 225 lead to apoptosis of beta cells. Further investigations are required to delineate these molecular 226 events.

227 Overall, NumbL depletion seems to be beneficial for the survival of beta cells under 228 diabetogenic conditions. To support this idea, we also observed that NumbL is significantly 
decreased in human Islets from prediabetic subjects, where there is expansion of functional beta cell mass. However, more investigations are warranted to validate NumbL as a drug target to treat diabetes.

Conclusion: In summary, the results of the present study suggest that NumbL and Mig6 are in an inactive complex under NG conditions and under GLT; they separate and Mig6 decreases

234 EGF signaling while NumbL increases NF-kB signaling. In addition, we uncovered a novel role 235 of NumbL in beta cell apoptosis under GLT. Future investigations will evaluate NumbL as a potential therapeutic target to prevent beta cell death under diabetogenic conditions.

\section{Methods:}

\subsection{Materials:}

The following antibodies were purchased from Cell Signaling Technologies (Denver, CO, 240 USA): phospho-EGFR, EGFR, p65, phosphor-p65, phosphor-elF2a, elF2a, Caspase-3 and 241 Cleaved Caspase-3 (Supporting Information Table S1). Antibodies to NumbL and TRAF6 242 were obtained from SantaCruz Biotechnology (Dallas, TX, USA). The sequence of siRNAs 243 (mission siRNAs purchased from Sigma-Aldrich, St. Louis, MO, USA) used against NumbL is: 244 5'- GAACUCACCUUUCAAACGU[dT][dT]-3'] \& 5'- ACGUUUGAAAGGUGAGUUC[dT][dT]-3' 245 and Numb is: 5'- GAAGACUGAUUUCCCAAUA[dT][dT]-3' \& $\quad$ 5'246 UAUUGGGAAAUCAGUCUUC[dT][dT]-3'; MISSION siRNA Universal Negative control was 247 used as a control. Cell culture media, RPMI-1640 \& CMRL-1066, were obtained from Thermo 248 Fisher Scientific (Waltham, MA, USA). All the other reagents, if not indicated, were purchased 249 from Sigma-Aldrich (St. Louis, MO, USA). 
Cadaveric human islets were procured from the Southern California Islet Resource Center

(City of Hope, Duarte, CA, USA) and cultured for $24 \mathrm{~h}$ in CMRL-1066 medium supplemented with $10 \%$ fetal bovine serum (FBS), $50 \mathrm{U} / \mathrm{mL}$ penicillin, and $50 \mathrm{ug} / \mathrm{mL}$ streptomycin before

254 starting the GLT experiments. Then, the human islets were cultured in CMRL-1066 medium 255 containing either $5 \mathrm{mM}$ glucose (NG condition) or $25 \mathrm{mM}$ glucose and $0.4 \mathrm{mM}$ sodium palmitate 256 (GLT condition) for various time points, as indicated in the figure legends. The islets were 257 collected at the indicated time points and washed twice in PBS before cell lysis in RIPA buffer 258 for immunoblot experiments. The protein lysates were loaded in a Wes instrument 259 (ProteinSimple, CA, USA) according to the manufacturer's protocol.

\subsection{2/13 cell culture and transfection:}

Ins-1-derived 832/13 cells were cultured as described previously in Ins-1 medium, consisting of RPMI-1640 medium supplemented with $10 \%$ FBS, $50 \mathrm{U} / \mathrm{mL}$ penicillin, $50 \mu \mathrm{g} / \mathrm{mL}$ streptomycin, $10 \mathrm{mM}$ HEPES pH 8.0 buffer, $2 \mathrm{mM}$ L-glutamine, $1 \mathrm{mM}$ sodium pyruvate and $0.05 \mathrm{mM}$ 2-

264 mercaptoethanol [25]. The cells were seeded in 6-well tissue culture plates and, after overnight 265 culture, were treated with $50 \mathrm{nM}$ of either Mission control Negative siRNA (siControl) or siRNAs specific against Numb or NumbL (siNumbL) for $48 \mathrm{~h}$. Then medium was replaced with either

267 normal glucose (NG) or GLT media for the indicated time periods, as described in the figure 268 legends.

\subsection{Glucolipotoxicity experiments with $832 / 13$ cells:}

832/13 cells were grown in Ins-1 medium until confluent and then cultured in Ins-1 medium

271 containing $25 \mathrm{mM}$ glucose \& $0.4 \mathrm{mM}$ palmitate for various time periods, as indicated in the 272 figure legends. For NG conditions, the cells were incubated in Ins-1 medium containing $11 \mathrm{mM}$ 273 glucose. 


\subsection{Co-immunoprecipitation of Mig6 binding partners:}

$832 / 13$ cells were grown in $15 \mathrm{~cm}$ round tissue culture dishes to near confluence and then

treated with adenoviruses expressing FLAG-tagged rat Mig6 (Ad-Flag-Mig6) or GFP (Ad-GFP) for $48 \mathrm{~h}$. The cells were then treated either $5 \mathrm{mM}$ glucose or $25 \mathrm{mM}$ glucose and $0.4 \mathrm{mM}$ palmitate for $12 \mathrm{~h}$. After the incubation, the cells were collected and sonicated for 10 seconds with $60 \%$ amplitude in cell lysis buffer $(20 \mathrm{mM}$ Tris PH 7.2, $150 \mathrm{mM} \mathrm{NaCl}, 1 \% \mathrm{NP}-40,1 \mathrm{mM}$ EDTA, $1 \mathrm{mM}$ EGTA, $1 \mathrm{mM} \mathrm{NaF}, 1 \mathrm{mM}$ sodium orthovanadate, $1 \mathrm{mM}$ PMSF and Roche's protease inhibitor tablet (Sigma-Aldrich, catalog \# 4693159001). The cell lysate was centrifuged at $14,000 \mathrm{xg}$ for $10 \mathrm{~min}$ to collect supernatant. Protein $\mathrm{A} / \mathrm{G}$ sepharose beads were equilibrated with cell lysis buffer and incubated with the supernatant for $12 \mathrm{~h}$ at $4^{\circ} \mathrm{C}$ with rotation. After the incubation, the beads were collected by centrifugation at $1000 \mathrm{xg}$ for $5 \mathrm{~min}$ and extensively washed in cell lysis buffer to remove non-specific binding proteins. The beads were then

286 incubated with elution buffer (cell lysis buffer $+500 \mu \mathrm{g} / \mathrm{mL}$ FLAG peptide) to specifically elute

287 FLAG-tagged Mig6 and its binding partners. The eluate was then further processed and peptides were identified with mass spectrometric analysis by the Multi-Omics Mass Spectrometry Core at the City of Hope.

\subsection{Apoptosis assay (cleaved caspase 3 activity assay):}

832/13 cells were treated with either NG or GLT for the indicated time points. After the 292 incubation, the cells were lysed in M-PER mammalian protein extraction reagent without 293 protease inhibitors and the supernatant was collected after centrifugation at $14000 \mathrm{xg}$ for 15 $294 \mathrm{~min}$. The protein concentration of the supernatant was determined by the BCA method. In a 96- 
emission wavelengths of $360 \mathrm{~nm}$ and $460 \mathrm{~nm}$, respectively. In the same plate, a standard curve was prepared with AMC (7-Amino-4-methylcoumarin) to quantify the caspase 3 activity.

\subsection{Proliferation assay (EdU incorporation):}

Cell proliferation was quantified using EdU incorporation assay, as described before [26, 27]. Briefly, nearly 5,000 cells were seeded in 8-well chamber plates and treated with either

302 siControl or siNumbL for $48 \mathrm{~h}$ and the incubated in GLT conditions for $12 \mathrm{~h}$ in the presence of

$30310 \mu \mathrm{M}$ EdU. The cells were then fixed with $4 \%$ formaldehyde for 30 min and permeabilized with $3040.5 \%$ Triton $\mathrm{X}-100$ for $15 \mathrm{~min}$. The cells were then incubated for $30 \mathrm{~min}$ with detection reagent 305 (100 mM Tris-Cl pH 8.5, $0.5 \mathrm{mM} \mathrm{CuSO}_{4}, 25 \mu \mathrm{M}$ sulfo-Cyanine 3 azide and $50 \mathrm{mM}$ ascorbic 306 acid). After the incubation, the cells were washed in PBS and mounted using Vectashield 307 mountant containing DAPI dye. Cell images were captured using a fluorescence microscope 308 and the number of DAPI- and EdU-stained cells was counted using ImageJ software.

3094.8 Immunoblotting:

310 After treatment, cells were lysed in RIPA buffer and centrifuged at $14000 \mathrm{xg}$ for 20 min to 311 collect supernatant. Protein concentrations were determined by the BCA method and equal 312 amounts of protein were run on SDS-PAGE gels. The proteins were then transferred to PVDF 313 membranes and immunoblotted. The following primary antibodies with the dilution factor of 1 : 3141000 were used for immunoblotting: caspase-3, NumbL, Numb, p65, phospho-p65, IkBa, FLAG, 315 TRAF6, $\mathrm{YH} 2 \mathrm{AX}$, phospho-elF2a and total elF2a. Tubulin and actin antibodies were used at 316 1:5000 dilutions. The following secondary antibodies were used: goat anti-mouse lgG-HRP 317 conjugate (1:5000) \& goat anti-rabbit lgG-HRP conjugate. The blots were developed using 318 Amersham ECL detection reagent (GE Healthcare, Chicago, IL, USA). For samples derived 319 from human islets, with a more limited amount of protein available, we performed the immune 
320 assay using the capillary Western-blot system (Wes, Protein Simple; San Jose, CA, USA), due

321 to the sensitivity compared to the traditional western-blot method. All experimental steps were

322 carried out according to the manufacturer's instructions.

3234.9 Glucose-stimulated insulin secretion (GSIS) assay:

832/13 cells were treated with siControl or siNumbL as described above (section 2.3) and

$32548 \mathrm{~h}$ after treatment, a GSIS assay was performed as previously described [28, 29]. Briefly,

326 cells were incubated in low glucose $(2.5 \mathrm{mM}) \mathrm{KRBB}$ buffer for $1 \mathrm{~h}$ and then incubated in KRBB

327 buffer containing low glucose $(2.5 \mathrm{mM})$ or high glucose $(15 \mathrm{mM})$ for $1 \mathrm{~h}$. The cells and media

328 were separated after the incubation and processed for quantification of insulin levels using the

329 RI-13K Rat Insulin RIA Kit (Millipore) according to the manufacturer's protocol.

\section{$330 \quad 4.10$ Statistical analysis:}

331 All the quantified data are presented as means \pm SEM. Student's $t$-tests for analysis of two 332 groups and ANOVA for analysis of more than two groups were employed to detect differences 333 between groups. Tukey's post hoc test was conducted after ANOVAs, and $p$-values of $<0.05$ 334 were considered statistically significant. 
Acknowledgements:

336 This work was supported by a National Institutes of Health grant DK099311 to PTF and a 337 Postdoctoral Fellowship Award from the American Heart Association to HDB. Human islets were 338 generously provided by the Southern California Islet Resource Center. Nancy Linford, PhD, 339 provided editing assistance. Research reported in this publication included work performed in 340 the Comprehensive Metabolic Phenotyping and the Mass Spectrometry and Proteomics Cores

341 at the City of Hope, with the latter supported by the National Cancer Institute of the National 342 Institutes of Health under grant number P30CA033572. The content is solely the responsibility 343 of the authors and does not necessarily represent the official views of the National Institutes of 344 Health. 


\section{References:}

346

1. Chen, C., et al., Human beta cell mass and function in diabetes: Recent advances in knowledge and technologies to understand disease pathogenesis. Mol Metab, 2017. 6(9): p. 943-957.

2. Karaca, M., C. Magnan, and C. Kargar, Functional pancreatic beta-cell mass: involvement in type 2 diabetes and therapeutic intervention. Diabetes Metab, 2009. 35(2): p. 77-84.

3. Sharma, R.B., et al., Insulin demand regulates $\beta$ cell number via the unfolded protein response. J Clin Invest, 2015. 125(10): p. 3831-46.

4. Laybutt, D.R., et al., Endoplasmic reticulum stress contributes to beta cell apoptosis in type 2 diabetes. Diabetologia, 2007. 50(4): p. 752-63.

5. Fonseca, S.G., J. Gromada, and F. Urano, Endoplasmic reticulum stress and pancreatic $\beta$-cell death. Trends Endocrinol Metab, 2011. 22(7): p. 266-74.

6. Poitout, V., Glucolipotoxicity of the pancreatic beta-cell: myth or reality? Biochem Soc Trans, 2008. 36(Pt 5): p. 901-4.

7. Unger, R.H. and S. Grundy, Hyperglycaemia as an inducer as well as a consequence of impaired islet cell function and insulin resistance: implications for the management of diabetes. Diabetologia, 1985. 28(3): p. 119-121.

8. Unger, R.H., Lipotoxicity in the Pathogenesis of Obesity-Dependent NIDDM: Genetic and Clinical Implications. Diabetes, 1995. 44(8): p. 863-870.

9. Prentki, M., et al., Malonyl-CoA Signaling, Lipid Partitioning, and Glucolipotoxicity. Role in $\beta$-Cell Adaptation and Failure in the Etiology of Diabetes, 2002. 51(suppl 3): p. S405S413.

10. Butler, A.E., et al., Beta-cell deficit and increased beta-cell apoptosis in humans with type 2 diabetes. Diabetes, 2003. 52(1): p. 102-10.

11. Cnop, M., et al., Mechanisms of Pancreatic $\beta$-Cell Death in Type 1 and Type 2 Diabetes. Many Differences, Few Similarities, 2005. 54(suppl 2): p. S97-S107.

12. Miettinen, P.J., et al., Downregulation of EGF receptor signaling in pancreatic islets causes diabetes due to impaired postnatal beta-cell growth. Diabetes, 2006. 55(12): p. 3299-308.

13. Bagnati, M., et al., Glucolipotoxicity initiates pancreatic beta-cell death through TNFR5/CD40-mediated STAT1 and NF-kappa B activation. Cell Death \& Disease, 2016. 7.

14. QiNan, W., et al., Par-4/NF-kappaB Mediates the Apoptosis of Islet beta Cells Induced by Glucolipotoxicity. J Diabetes Res, 2016. 2016: p. 4692478.

15. Zhang, Q., M.J. Lenardo, and D. Baltimore, 30 Years of NF-kappaB: A Blossoming of Relevance to Human Pathobiology. Cell, 2017. 168(1-2): p. 37-57.

16. Chen, Z.J., Ubiquitin signalling in the NF-kappaB pathway. Nat Cell Biol, 2005. 7(8): p. 758-65.

17. Miettinen, P., et al., EGF receptor in pancreatic beta-cell mass regulation. Biochem Soc Trans, 2008. 36(Pt 3): p. 280-5.

18. Brand, S.J., et al., Pharmacological treatment of chronic diabetes by stimulating pancreatic beta-cell regeneration with systemic co-administration of EGF and gastrin. Pharmacol Toxicol, 2002. 91(6): p. 414-20.

19. Chen, Y.C., et al., Mig6 haploinsufficiency protects mice against streptozotocin-induced diabetes. Diabetologia, 2014. 57(10): p. 2066-75. 
20. Chen, Y.C., et al., Mitogen-inducible gene 6 triggers apoptosis and exacerbates ER stress-induced beta-cell death. Mol Endocrinol, 2013. 27(1): p. 162-71.

21. Colvin, E.S., et al., Glucocorticoid-induced suppression of beta-cell proliferation is mediated by Mig6. Endocrinology, 2013. 154(3): p. 1039-46.

22. Fiorentino, L., et al., Inhibition of ErbB-2 Mitogenic and Transforming Activity by RALT, a Mitogen-Induced Signal Transducer Which Binds to the ErbB-2 Kinase Domain. Molecular and Cellular Biology, 2000. 20(20): p. 7735-7750.

23. Chapman, G., et al., High levels of Notch signaling down-regulate Numb and Numblike. J Cell Biol, 2006. 175(4): p. 535-40.

24. Zhong, W., et al., Differential expression of mammalian Numb, Numblike and Notch1 suggests distinct roles during mouse cortical neurogenesis. Development, 1997. 124(10): p. 1887-97.

25. Hohmeier, H.E., et al., Isolation of INS-1-derived cell lines with robust ATP-sensitive K+ channel-dependent and -independent glucose-stimulated insulin secretion. Diabetes, 2000. 49(3): p. 424-30.

26. Basavarajappa, H.D., et al., Synthesis and Biological Evaluation of Novel Homoisoflavonoids for Retinal Neovascularization. J Med Chem, 2015. 58(12): p. 50155027.

27. Salic, A. and T.J. Mitchison, A chemical method for fast and sensitive detection of DNA synthesis in vivo. Proc Natl Acad Sci U S A, 2008. 105(7): p. 2415-20.

28. Fueger, P.T., et al., Trefoil factor 3 stimulates human and rodent pancreatic islet betacell replication with retention of function. Mol Endocrinol, 2008. 22(5): p. 1251-9.

29. Hohmeier, H.E., et al., Regulation of Insulin Secretion From Novel Engineered Insulinoma Cell Lines. Diabetes, 1997. 46(6): p. 968-977.

30. Makkinje, A., et al., Gene 33/Mig-6, a transcriptionally inducible adapter protein that binds GTP-Cdc42 and activates SAPK/JNK. A potential marker transcript for chronic pathologic conditions, such as diabetic nephropathy. Possible role in the response to persistent stress. J Biol Chem, 2000. 275(23): p. 17838-47.

31. Poitout, V. and R.P. Robertson, Glucolipotoxicity: fuel excess and beta-cell dysfunction. Endocr Rev, 2008. 29(3): p. 351-66.

32. Poitout, V., et al., Glucolipotoxicity of the pancreatic beta cell. Biochim Biophys Acta, 2010. 1801(3): p. 289-98.

33. Yingjie, L., et al., Numblike regulates proliferation, apoptosis, and invasion of lung cancer cell. Tumour Biol, 2013. 34(5): p. 2773-80.

34. Hirai, M., et al., Adaptor proteins NUMB and NUMBL promote cell cycle withdrawal by targeting ERBB2 for degradation. J Clin Invest, 2017. 127(2): p. 569-582.

35. Melloul, D., Role of NF-kappaB in beta-cell death. Biochem Soc Trans, 2008. 36(Pt 3): $\mathrm{p}$. 334-9.

36. Eldor, R., et al., Conditional and specific NF-kB blockade protects pancreatic beta cells from diabetogenic agents. Proceedings of the National Academy of Sciences of the United States of America, 2006. 103(13): p. 5072-5077.

37. Zhou, L., et al., NUMBL interacts with TRAF6 and promotes the degradation of TRAF6. Biochem Biophys Res Commun, 2010. 392(3): p. 409-14.

38. Swarnkar, G., et al., NUMBL Interacts with TAK1, TRAF6 and NEMO to Negatively Regulate NF-KB Signaling During Osteoclastogenesis. Scientific Reports, 2017. 7(1): p. 12600.

39. Zarzycka, B., et al., Discovery of small molecule CD40-TRAF6 inhibitors. J Chem Inf Model, 2015. 55(2): p. 294-307. 
bioRxiv preprint doi: https://doi.org/10.1101/2020.08.16.253286; this version posted August 16, 2020. The copyright holder for this preprint

(which was not certified by peer review) is the author/funder, who has granted bioRxiv a license to display the preprint in perpetuity. It is made available under aCC-BY-NC-ND 4.0 International license.

439 40. Park, E., et al., Structure and mechanism of activity-based inhibition of the EGF receptor 440 by Mig6. Nat Struct Mol Biol, 2015. 22(9): p. 703-711.

441 41. Hostager, B.S. and G.A. Bishop, CD40-Mediated Activation of the NF-kB2 Pathway.

442 Front Immunol, 2013. 4: p. 376. 


\section{Figure Legends:}

445 Figure 1: Mig6 interacts with NumbL under NG and this interaction is disrupted under GLT

446 conditions: (A) Venn diagram depicting number of proteins pulled down with Flag-Mig6 under

447 NG and GLT conditions. (B) The fold change in number of peptide counts of each pulled down

448 protein under GLT and NG conditions is plotted against P-values of Fisher's exact $t$-test to

449 screen for proteins with significantly altered binding pattern with Mig6. (C) the number of unique

450 peptide counts of NumbL protein identified from eluate samples (normalized to total spectral

451 count of the eluate samples). (D) Representative immunoblot from co-immunoprecipitation

452 experiments confirming the interaction between NumbL and Mig6 under NG and GLT

453 conditions. GLT, glucolipotoxicity; NG, normal glucose.

454 Figure 2: NumbL expression levels are unchanged in beta cells under GLT conditions: (A) 455 mRNA levels of NumbL in 832/13 cells after culture in GLT conditions for the indicated time 456 periods. (B) Protein levels of NumbL in 832/13 cells after culture in GLT conditions for indicated 457 time periods. (C) mRNA levels of NumbL in human islets obtained from normal, prediabetic and 458 diabetic patients. * $p<0.05$ vs. normal. (D) mRNA levels of NumbL in human islets after culture 459 in NG and GLT conditions for 48 h. All data are represented as Mean +/- SEM and were compared by ANOVA.

461 Figure 3: siRNA-mediated knock down of NumbL inhibits GLT-induced apoptosis of Ins1 $462832 / 13$ cells. (A) Cleaved caspase 3 activity after exposure of cells to GLT for the indicated time 463 periods. (B) Representative blot and quantification of NumbL protein levels from cells treated 464 with a control RNAi (siControl) or RNAi to NumbL (siNumbL). * $\mathrm{P}<0.05$ ( $t$-test). (C) 465 Representative blot and quantification of cleaved caspase-3 protein from cells treated with 466 siNumbL either under NG or GLT for 12 h. * $p<0.05$ vs. siControl treated under NG; \#p<0.05 vs. 
467 siControl treated under GLT (ANOVA). (D) Cleaved caspase-3 activity in siRNA-treated cells

468 after culture in NG and GLT conditions for 12 h. ${ }^{*} p<0.05$ vs. siControl treated with NG; \#p<0.05

469 vs. siControl treated with GLT. The data are representative from at least three independent

470 experiments.

471 Figure 4: NumbL downregulation prevents GLT-mediated activation of NF-KB signaling. (A) \&

472 (B) Representative histogram and immunoblot of IkBa protein using the capillary Western-blot

473 system from human islets treated with GLT conditions for the indicated time periods. (C)

474 Quantification of IkBa protein. The quantification data are from three independent experiments.

475 *p<0.05 vs. '0 hr GLT' group. (D) \& (E) Representative immunoblot and quantification of IkBa

476 protein from siRNA-treated $832 / 13$ Ins1 cells cultured in NG or GLT conditions for 12 h. * $p<0.05$

477 vs. siControl group under NG. (F) \& (G) Representative immunoblot and quantification of

478 phospho-p65 protein from siRNA treated 832/13 Ins1 cells cultured in NG or GLT conditions for

47912 hours. * $p<0.05$ vs. siControl group under NG; \#p<0.05 vs. siControl group under GLT.

480 Figure 5: NumbL interaction with TRAF6 is increased under GLT conditions. (A) Representative 481 blot of TRAF6 proteins pulled down using an anti-NumbL antibody. (B) Representative blot of

482 TRAF6 protein and quantification of TRAF6 protein levels in cells treated with GLT for the 483 indicated time periods. (C \& D) Effect of TRAF6 inhibitor 6877002 on the levels of IkBa and

484 Cleaved caspase-3 proteins in beta cells exposed to GLT for $12 \mathrm{~h}$. (E) Proposed model of 485 interactions between Mig6, NumbL \& TRAF6 on EGFR and NFkB signaling in beta cells. *p< 4860.05 vs. DMSO control under NG condition and \#p<0.05 vs. DMSO control under GLT 487 condition. 


\section{Supporting Information:}

Figure S1: siRNA-mediated knock down of NumbL does not prevent GLT-induced ER-stress.

(A) \& (B) representative immunoblot and quantification of ER-stress marker proteins phospho-

elF2 $a$ and total elF2a. 832/13 Ins1 cells were treated with NG or GLT conditions for 12 hours. ${ }^{*} p<0.05$ vs. siControl group under NG \& ns; $p>0.05$.

Figure S2: NumbL down regulation does not affect the proliferation and insulin secretion capacity of beta cells. (A) Quantification of beta cell proliferation using EdU incorporation assay in siNumbL- or siControl-treated cells under NG or GLT conditions for $12 \mathrm{~h}$. (B) NumbL down regulation does not rescue impairment of EGF signaling under GLT. Representative immunoblot of phospho-EGFR and total EGFR proteins from siNumbL- or siControl-treated cells cultured under NG or GLT for $12 \mathrm{~h}$. After incubation, the cells were exposed to either 0,5 or 15 min of EGF ligand. Quantification of phospho-EGFR levels from EGF treated samples for 0 (-) and 5 $\min (+)$ are shown. * $p<0.05$ vs. siControl with 5 min EGF group under NG. (C) Quantification of

501 glucose-stimulated Insulin secretion capacity of Ins1 832/13 cells in siNumbL- or siControl-

502 treated cells. ${ }^{*} p<0.05$ vs. siControl group under NG \& ns; $p>0.05$.

503 Figure S3: NumbL down regulation does not affect Notch signaling in beta cells. (A)

504 Quantification of Hes-1 mRNA levels in siNumbL- or siControl-treated cells. (B) Quantification of 505 Hes-1 mRNA levels in siNumb or siControl treated cells. Cells were treated with NG or GLT 506 conditions for 12 h. ${ }^{*} p<0.05$ vs. siControl group under NG \& ns; $p>0.05$. 
507 Supporting Information - Table 1: The details of the antibodies used in the manuscript:

\begin{tabular}{|c|c|c|c|}
\hline Antibody & Company & Catalog \# & Dilution \\
\hline Phospho-EGFR (Y1173) & Invitrogen & $44794 G$ & $1: 1000$ \\
\hline EGFR & Cell Signaling Technology & 2232 & $1: 1000$ \\
\hline NUMB & Cell Signaling Technology & 2756 & $1: 1000$ \\
\hline NUMBL & Santa Cruz Biotechnology & SC-390590 & $1: 1000$ \\
\hline Phospho-p65 & Cell Signaling Technology & 3031 & $1: 1000$ \\
\hline p65 & Cell Signaling Technology & 8242 & $1: 1000$ \\
\hline Phospho-elF2a (S51) & Cell Signaling Technology & 9721 & $1: 1000$ \\
\hline elF2a & Cell Signaling Technology & 5324 & $1: 1000$ \\
\hline Caspase-3 & Cell Signaling Technology & 9662 & $1: 1000$ \\
\hline Cleaved Caspase-3 & Cell Signaling Technology & 9664 & $1: 1000$ \\
\hline TRAF6 & Santa Cruz Biotechnology & SC-8409 & $1: 1000$ \\
\hline Tubulin & Cell Signaling Technology & 2144 & $1: 1000$ \\
\hline Actin & Millipore Sigma & MAB1501 & $1: 1000$ \\
\hline
\end{tabular}




\section{Figure 1}

A

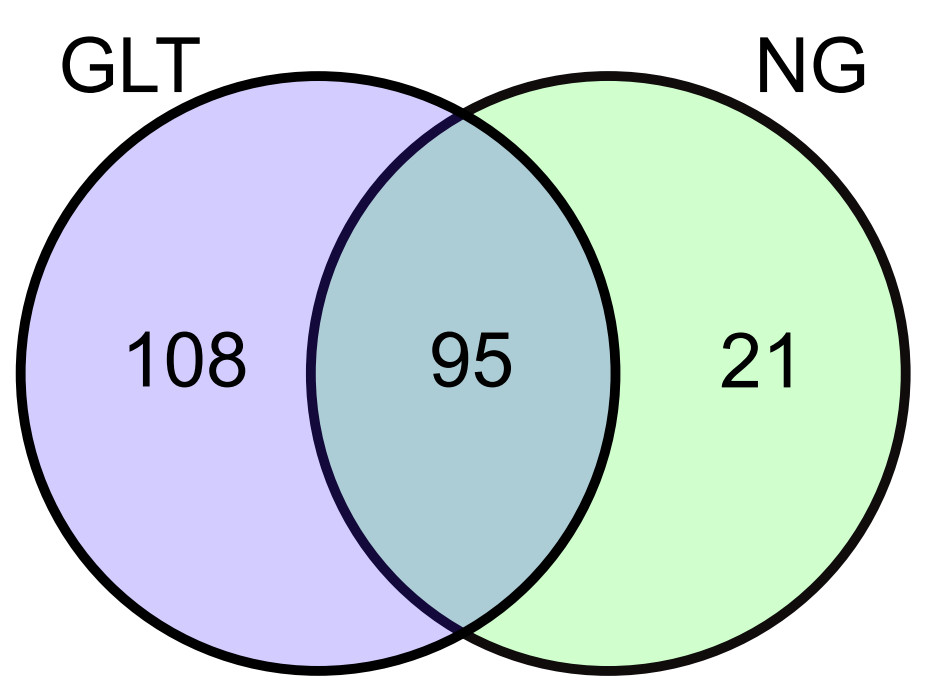

B
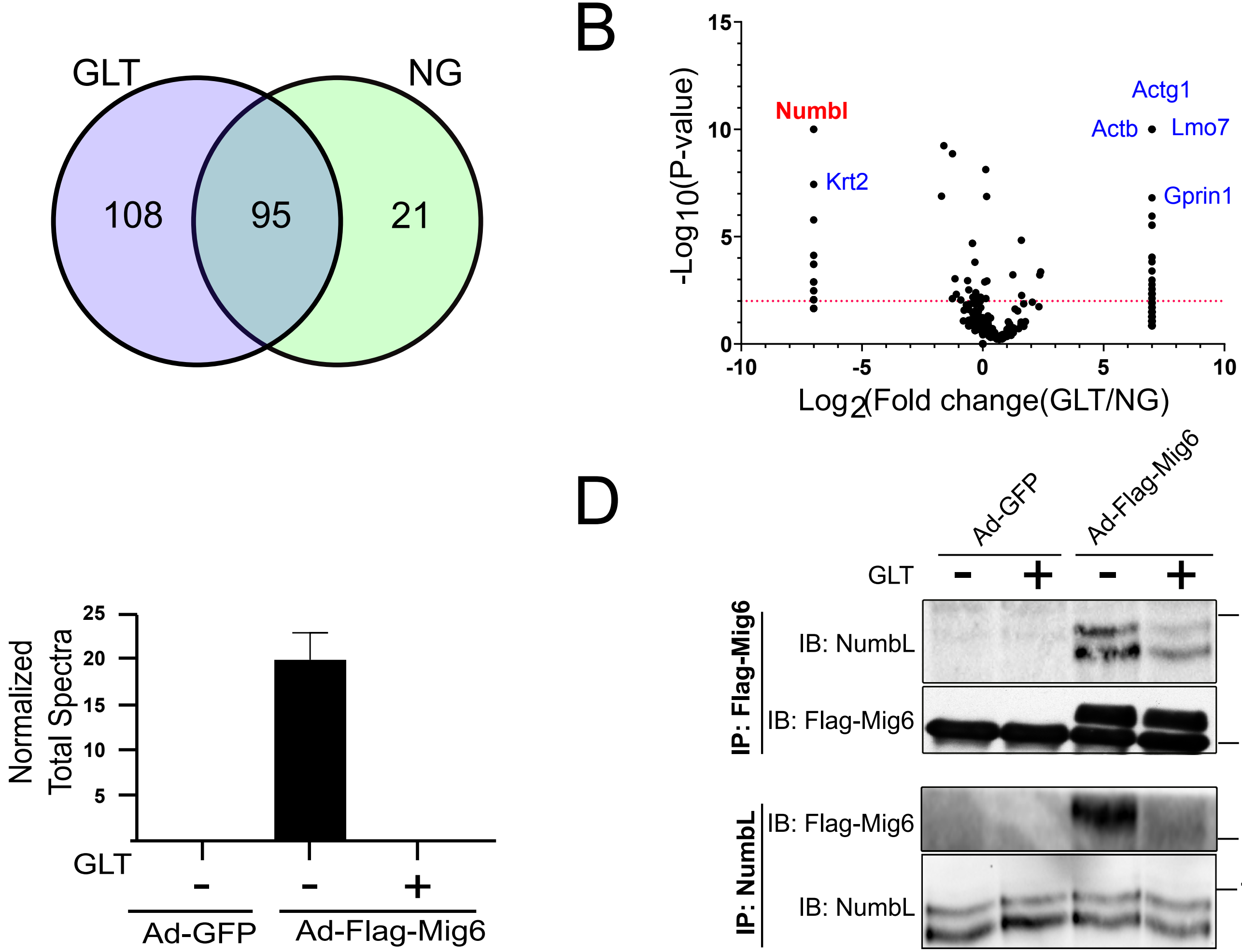

D
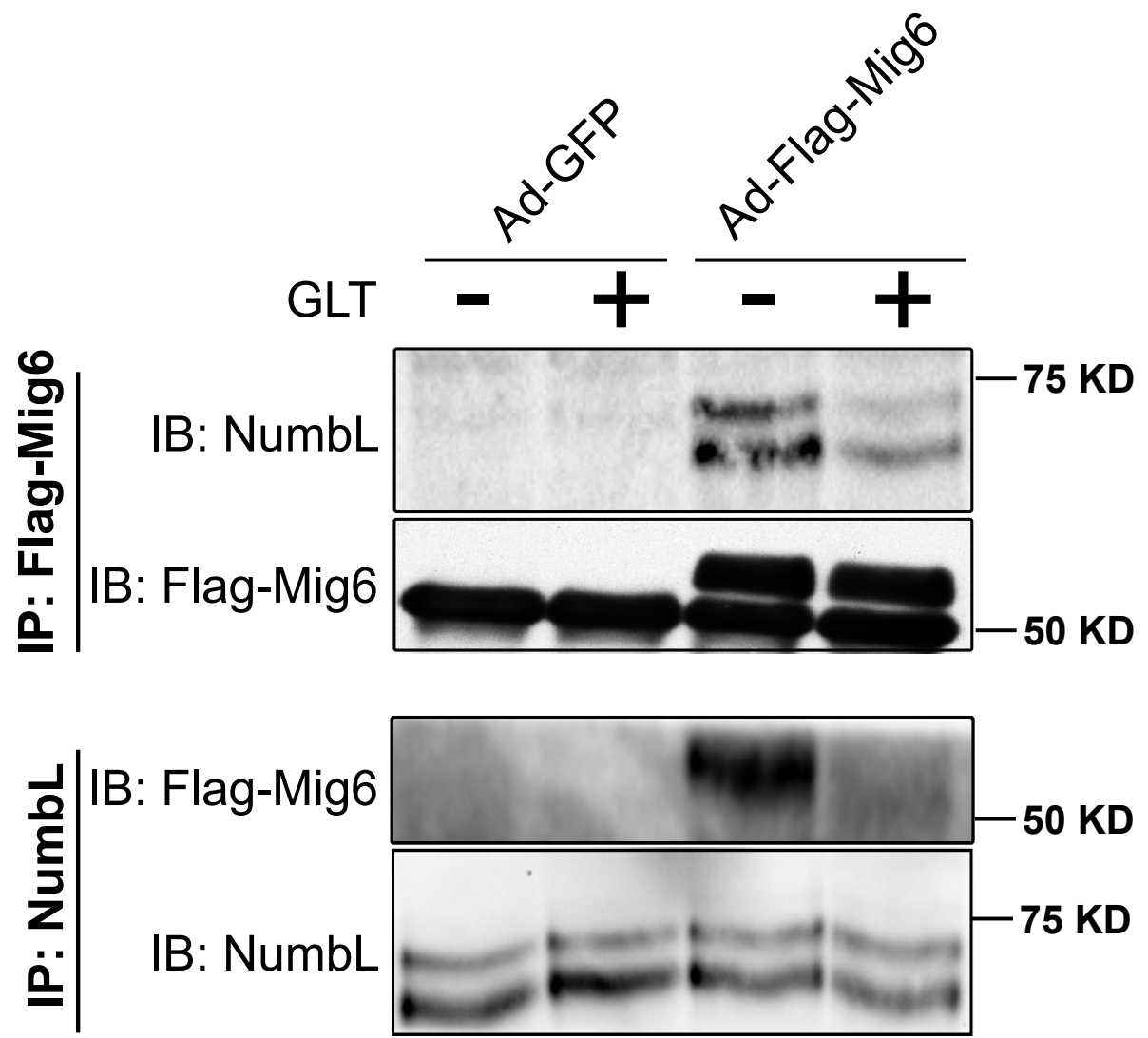


\section{Figure 2:}

A

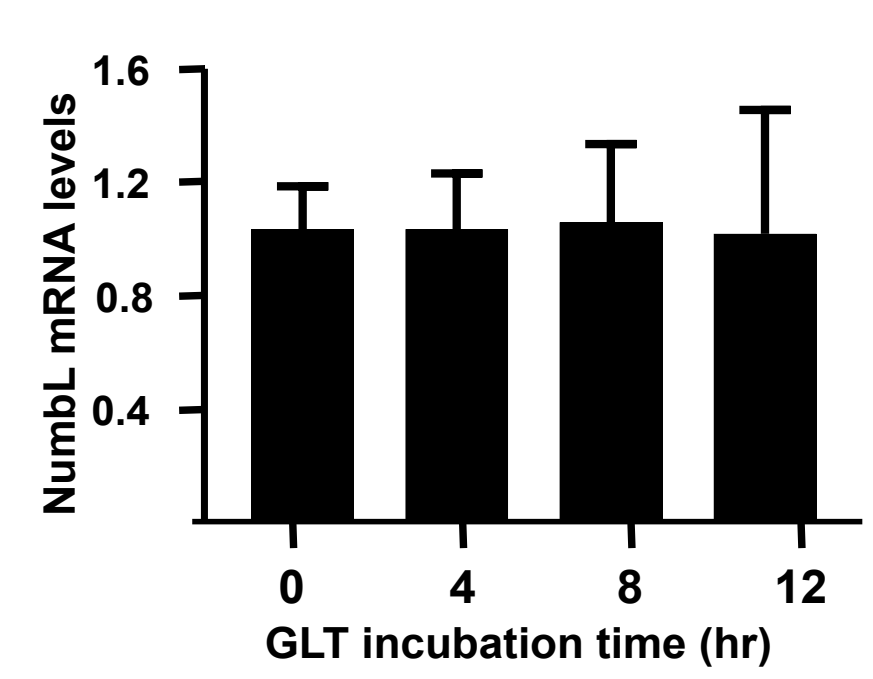

C

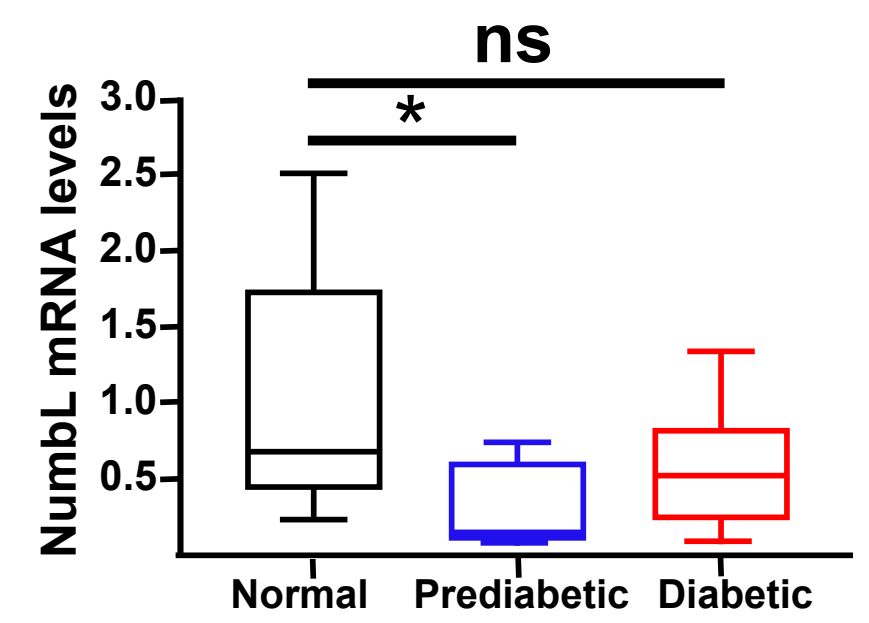

B

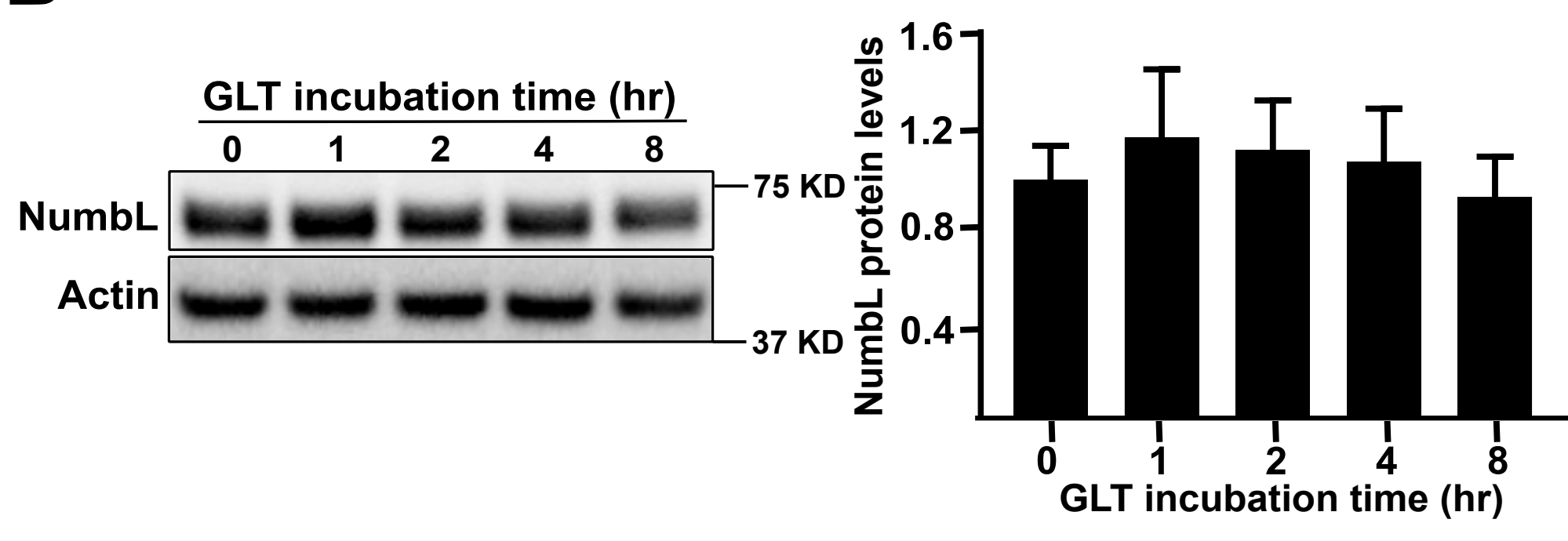

D

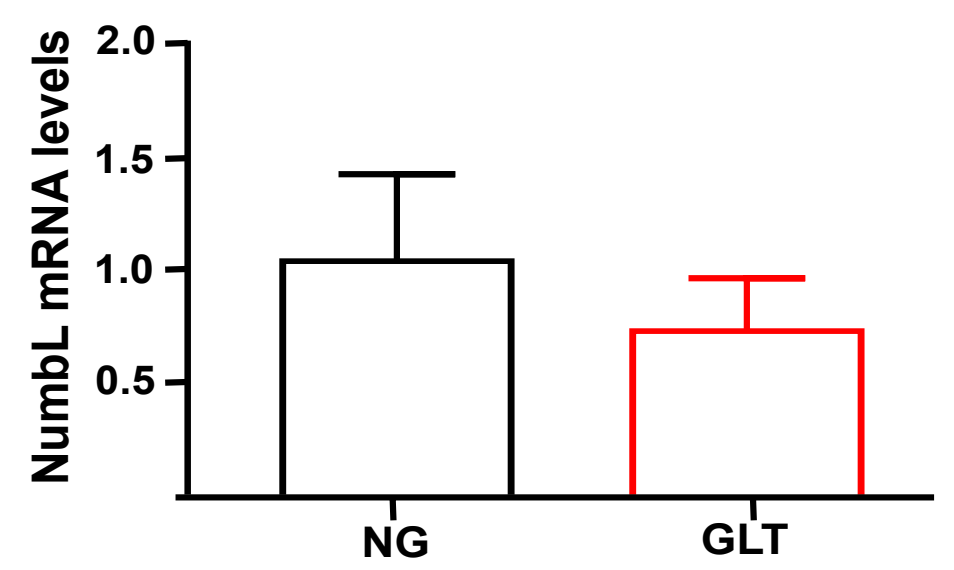




\section{Figure 4:}

\section{A}

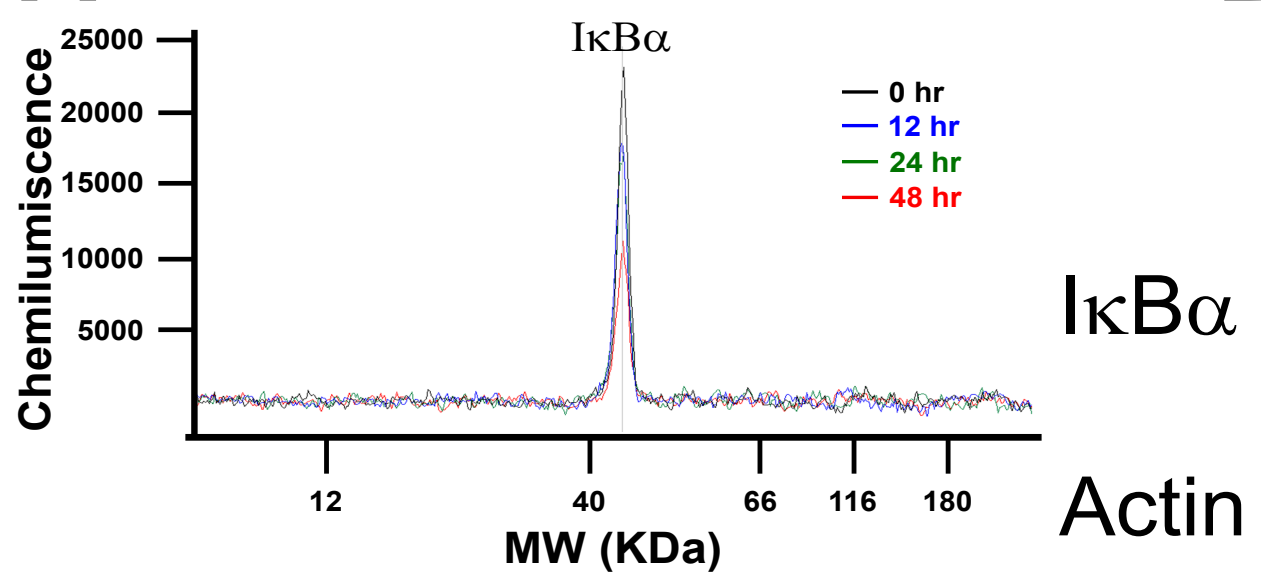

D
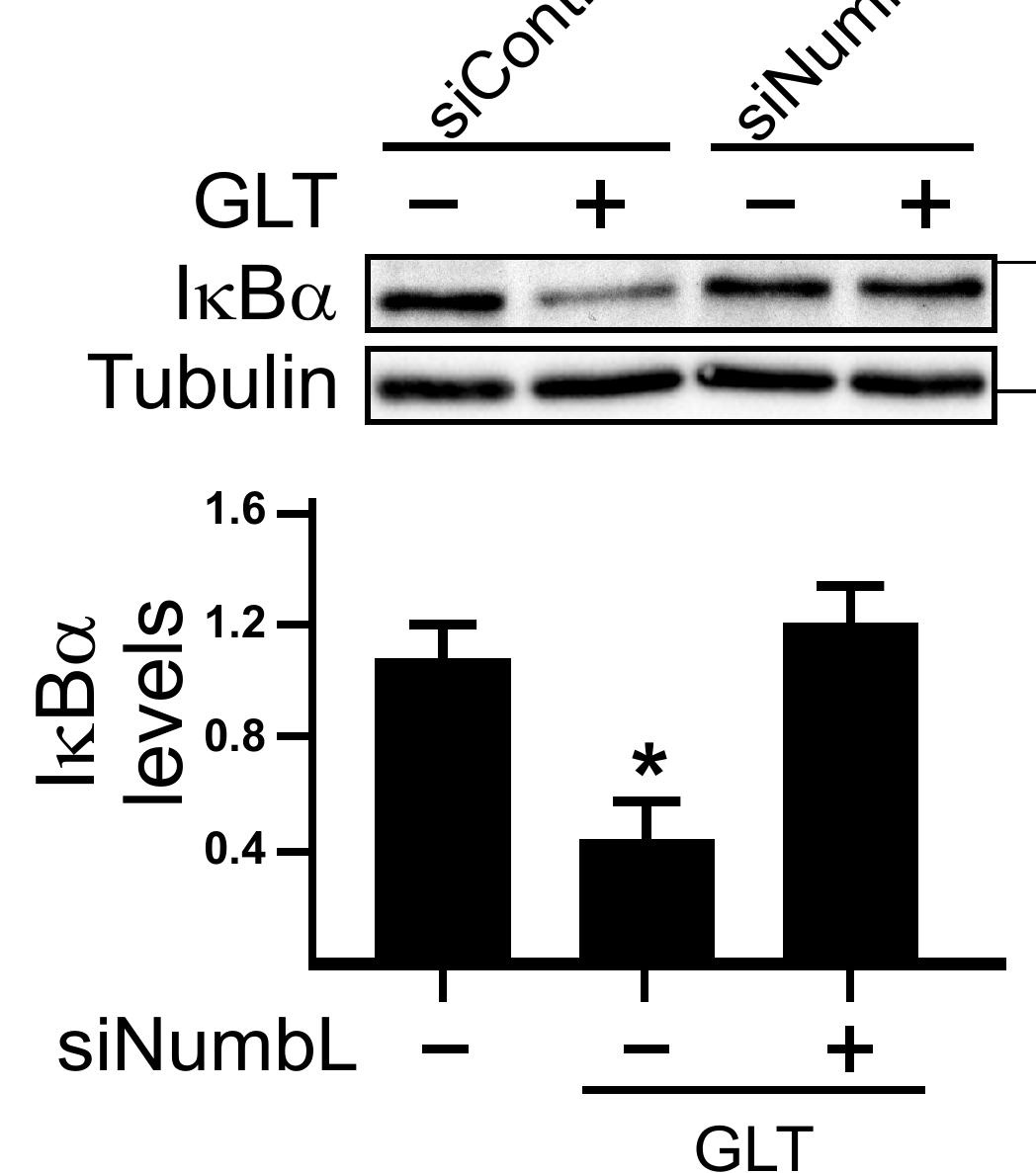

$\operatorname{l\kappa } \mathrm{B} \alpha$

Tubulin

$$
\text { - }
$$



B

Incubation time (hr) $\begin{array}{llll}0 & 12 & 24 & 48\end{array}$

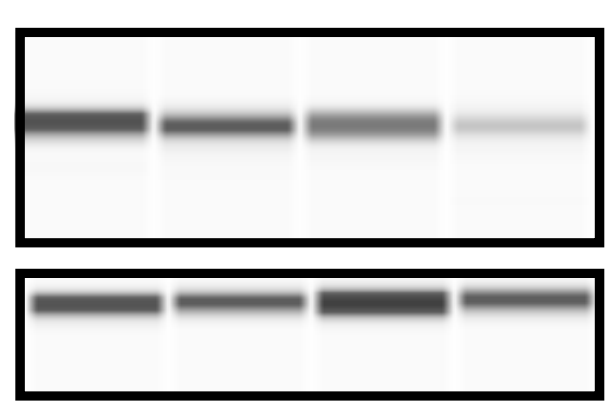

E

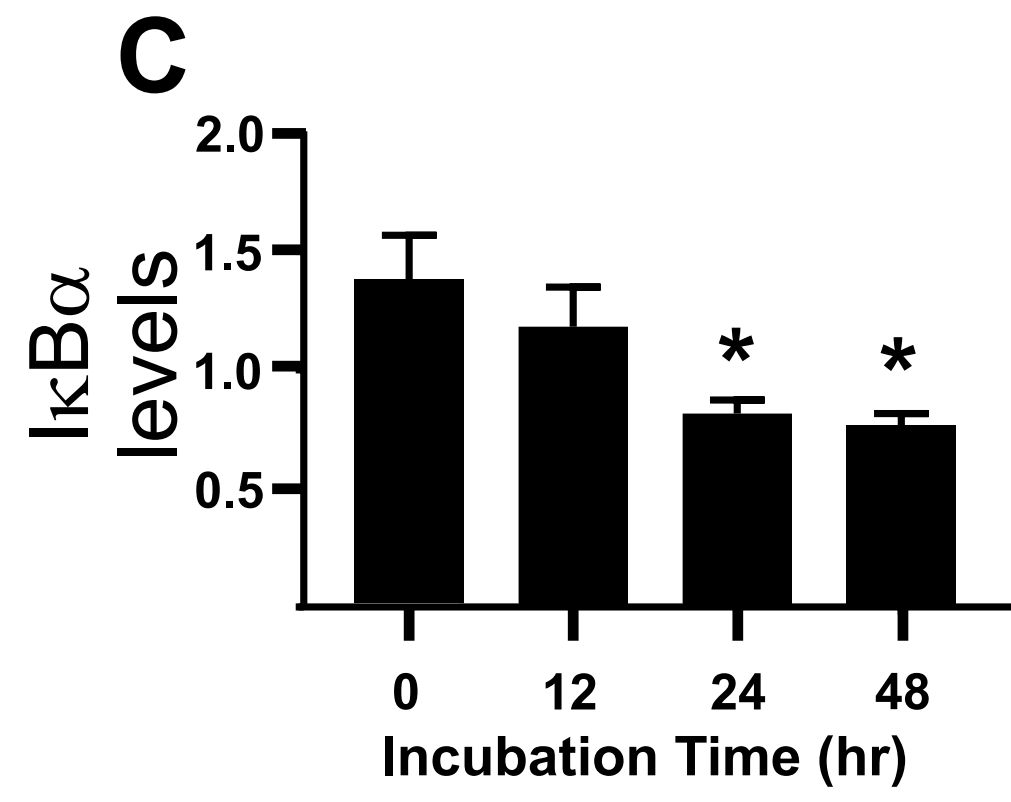

\section{$E$}

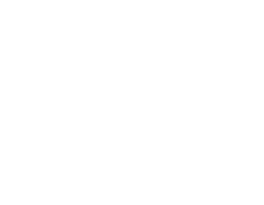

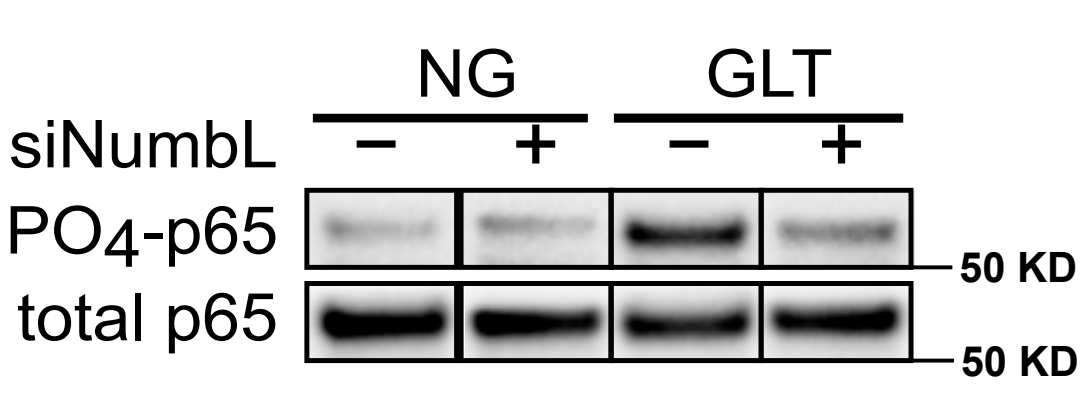

$G$

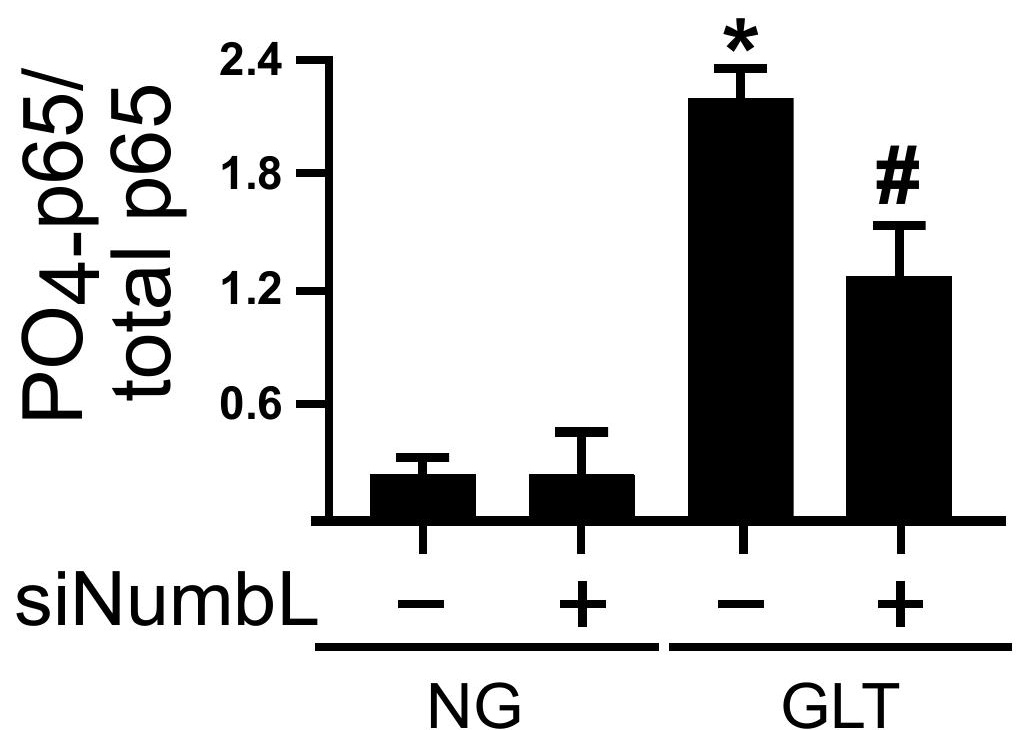


Figure 5:

A
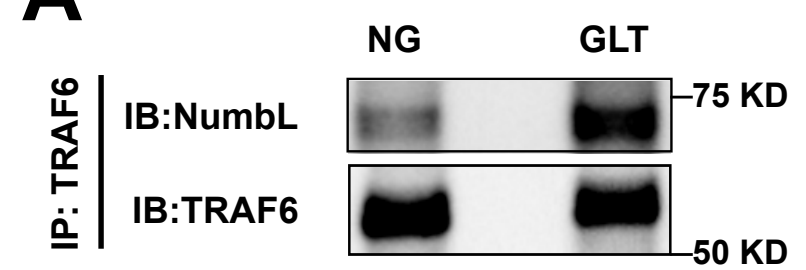

0

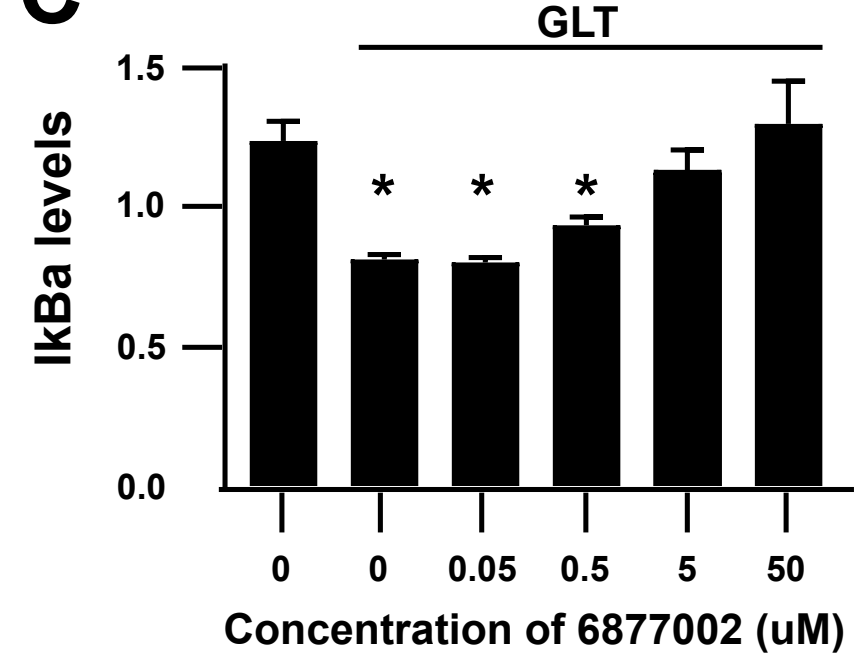

B

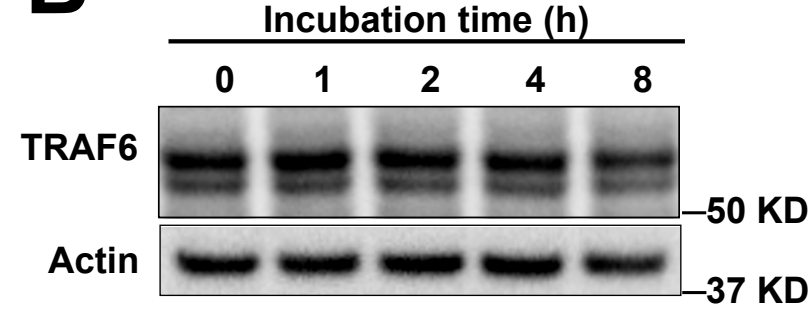

D

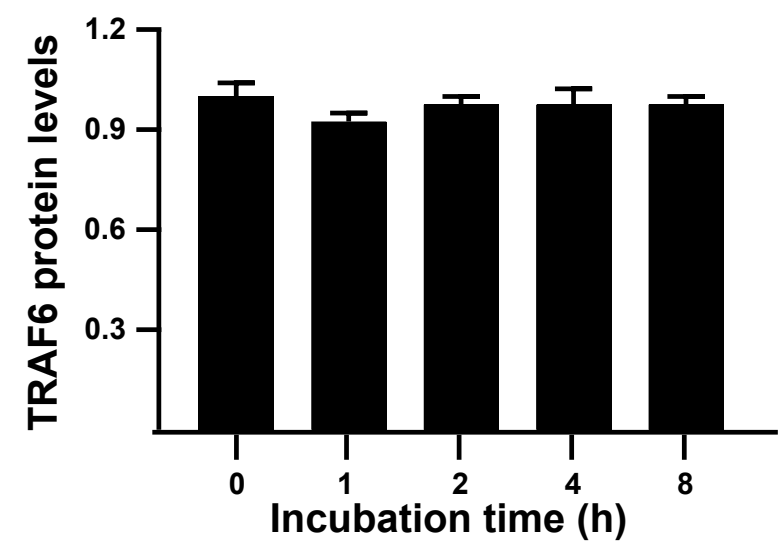

GLT

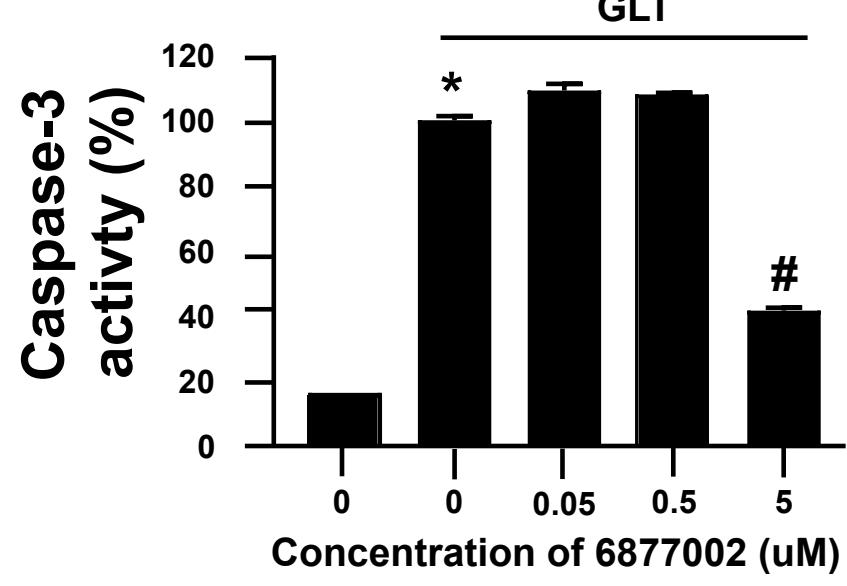

E

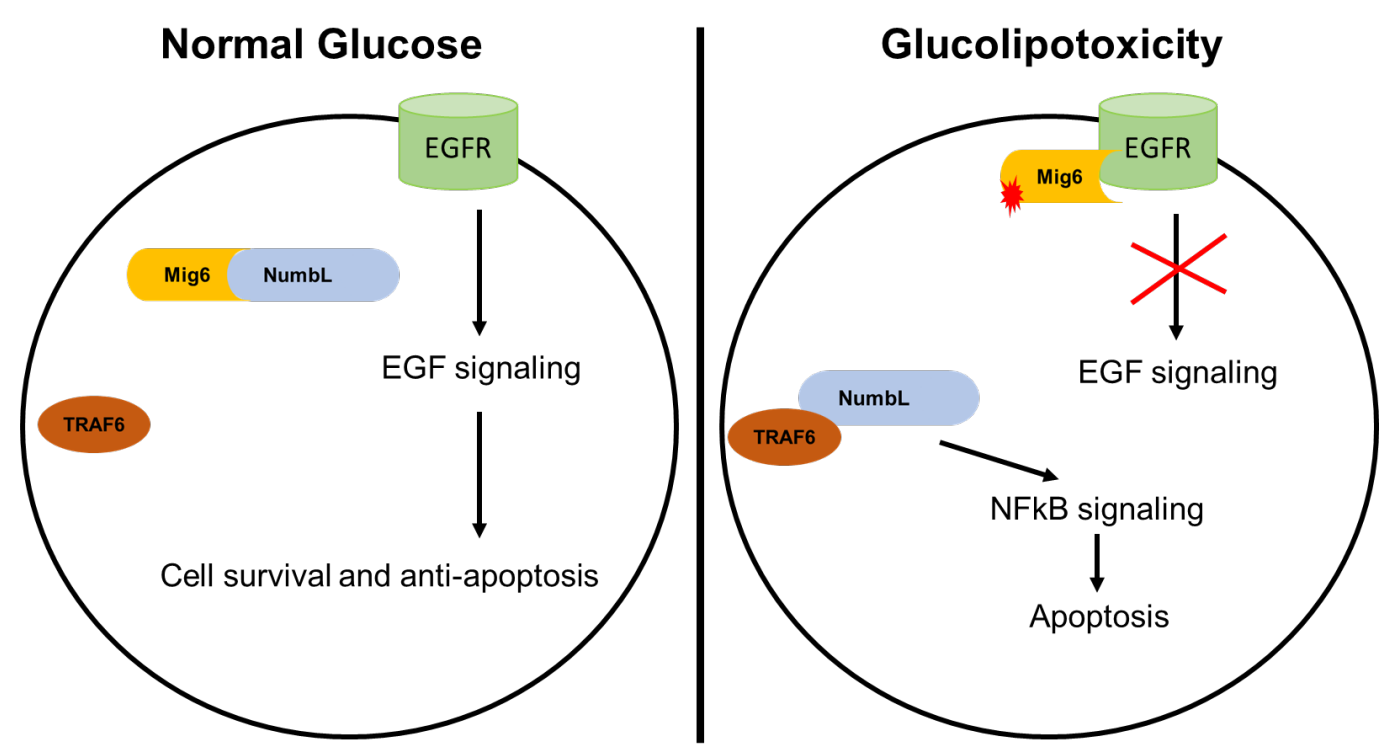


bioRxiv preprint doi: https://doi.org/10.1101/2020.08.16.253286; throxsion posted August 16, 2020. The copyrigh od der for this preprint (which was not certified by peer review) is the author/funder, who hagranted bioRxiv a license to display the prepkinm in perpetuity. It is made available under aCC-BDC-ND 4.0 International license.
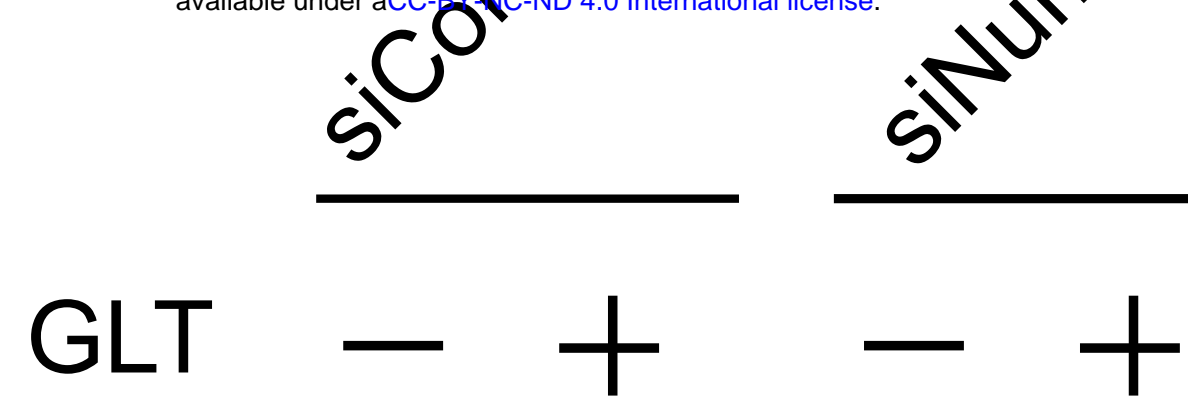

\section{Phospho-elF2a}



Total-elF2a

Supporting Information Figure S2:

A


B
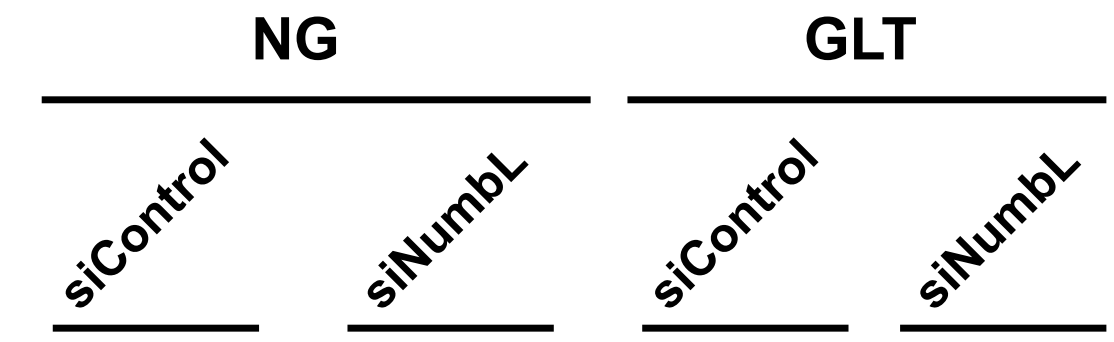

Time (min) $0515 \quad 0515 \quad 0515 \quad 0515$

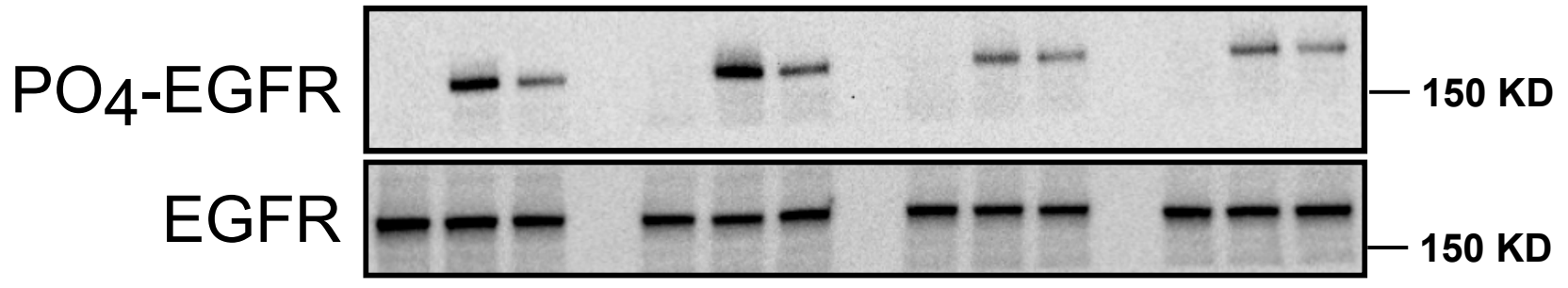

$2.5 \mathrm{mM}$ GIc

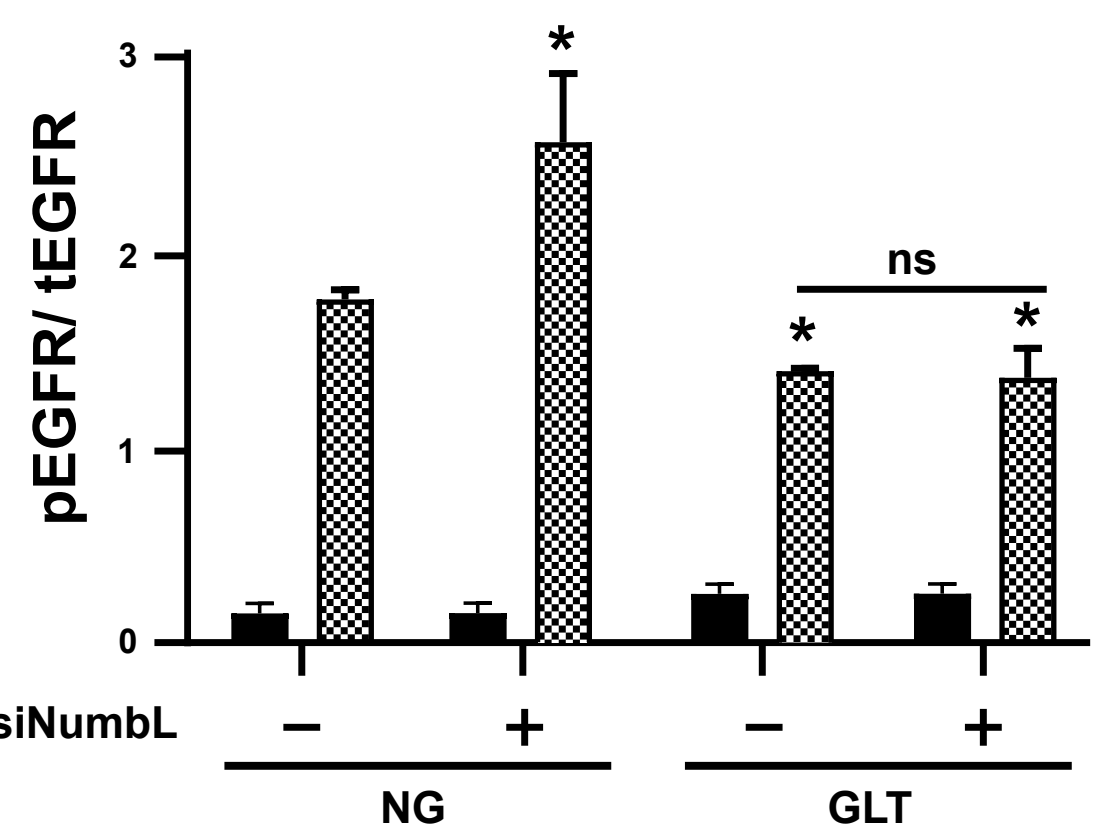
$\otimes 20 \mathrm{mM}$ Glc 
R Rxiv preprint doi: https://doi.org/10.1101/2020.08.16.253286; this version posted August 16, 2020. The copyright holder for this preprint h was not certified by peer review) is the author/funder, who has granted bioRxiv a license to display the preprint in perpetuity. It is made

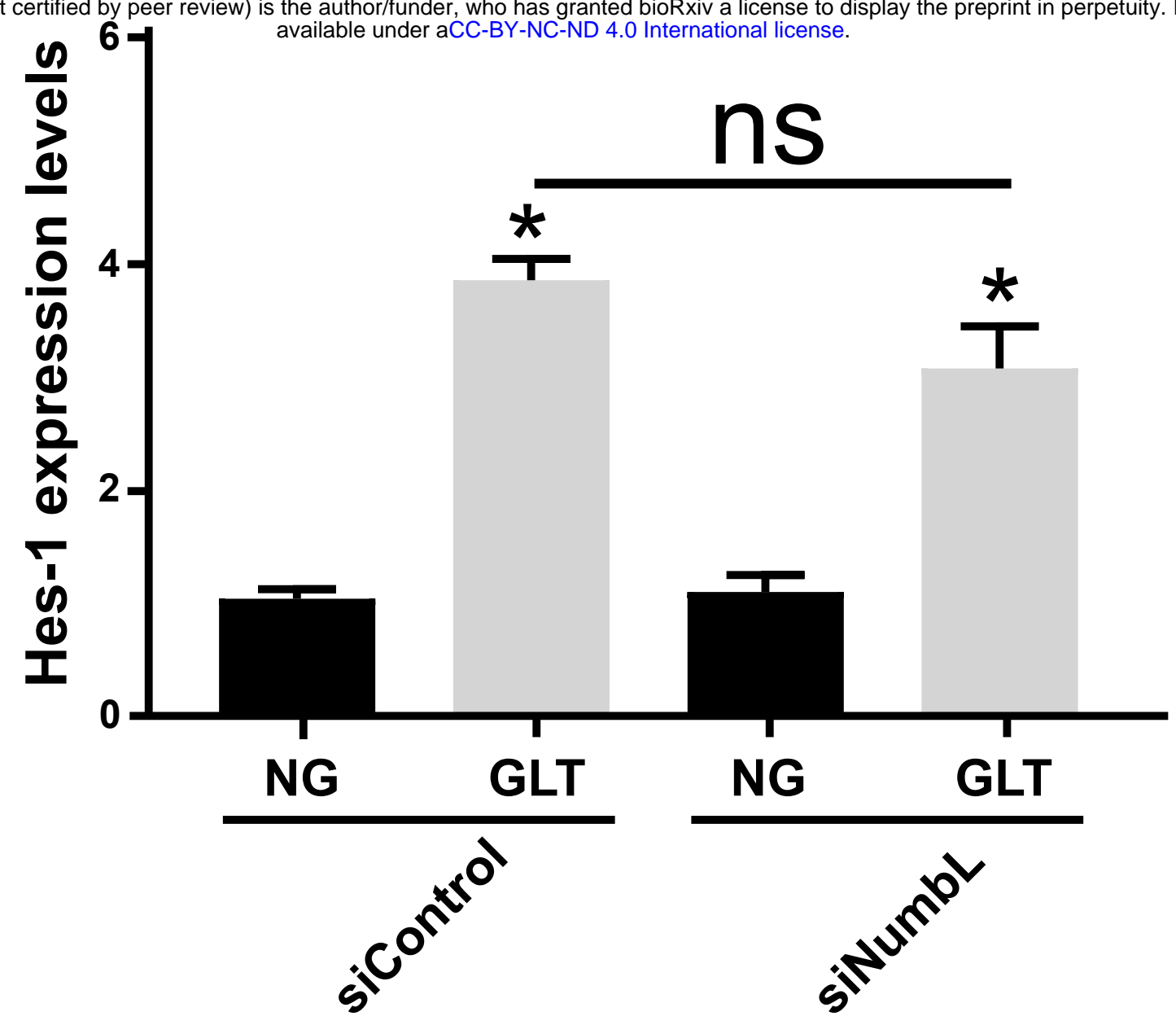

B

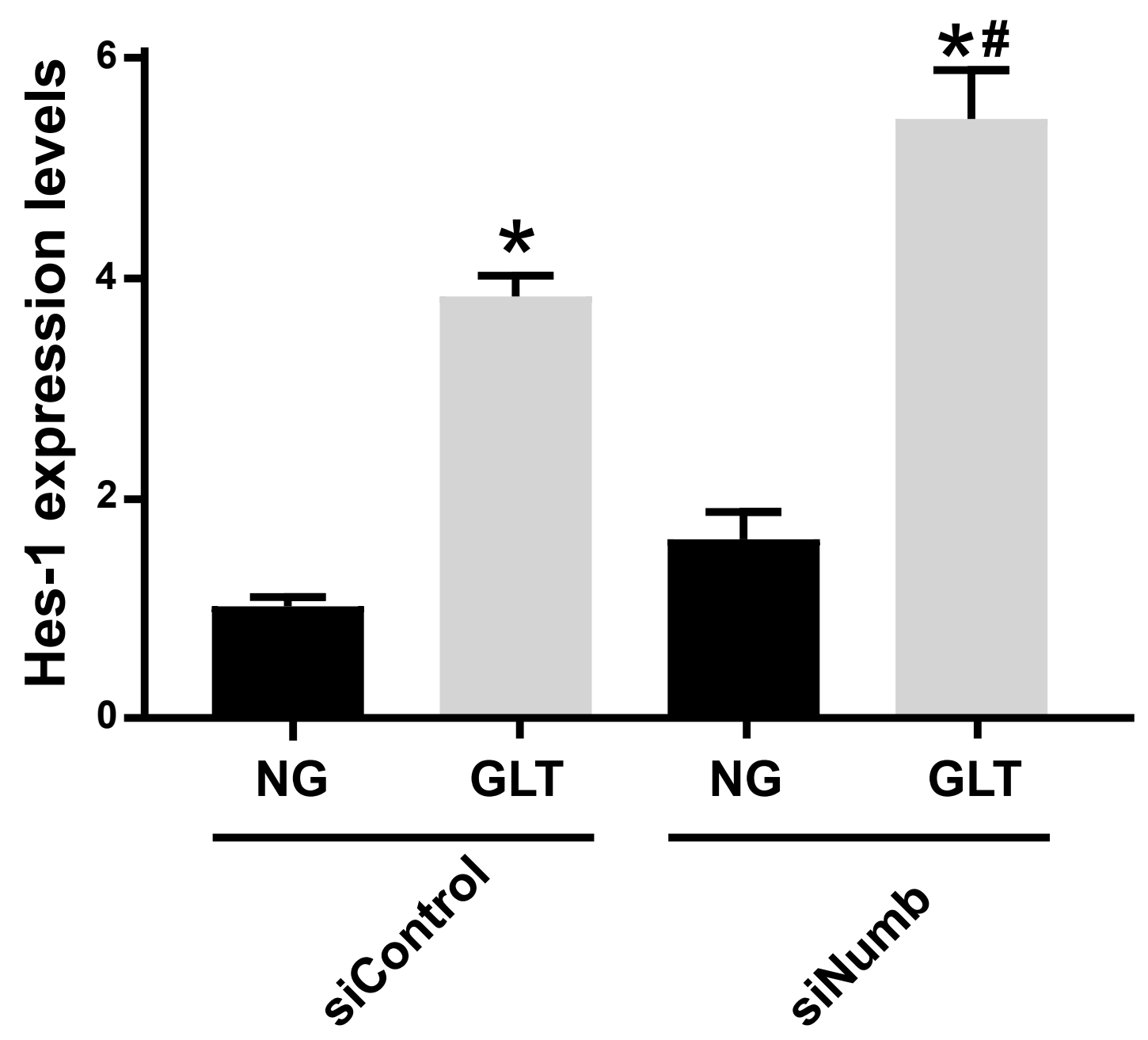

